\title{
GAMIFICATION AT WORK: HOW 5 STARS COULD HELP MOTIVATING PEOPLE
}

\author{
Riduan*, Chotimatuzzahra, Suyadi \\ Management Department, Sekolah Tinggi IImu Ekonomi Muhammadiyah Kalianda, \\ Indonesia \\ *E-mail: riduanmob@yahoo.co.id
}

\begin{abstract}
Gamification is one of the digitization and automation techniques that can be utilized in a job. In Go-Jek (one of the online motorcycle-taxi applications), there are gamification elements such as points, penalties and prizes, instant feedbacks, performance, and so on. Therefore, the aim of this study is to determine the influence of gamification on the work motivation of Go-Jek partners. This study is explanatory research that was conducted by using ANOVA with a quantitative approach. The respondents were Go-Jek partners who have worked for more than one year. From the results, it can be said that industry 4.0 can incorporate gamification elements in its working system to increase people work motivation.
\end{abstract}

\section{KEY WORDS}

Gamification, work, motivation, Go-Jek partners.

Industry 4.0, which is recognized by digitalization and automation, is expected to drive massive changes in the entire industry. In addition to the changes in production modes, this can affect the work mechanism and workforce of a company. Automation with machines is considered to be able to replace the jobs that are usually done by human labor. These developments make few parties feel that this new era could threaten local human resources.

Indeed, Industry 4.0 does not have to be interpreted like that. Digitalization and automation must be interpreted wisely and carefully. Barr in MacRae (2018) said that Industry 4.0 is a level where cyber elements capture and increase human capital and thought. This enhancement is expected to affect the mindset and resolution of a problem. In other words, this actually helps the people to improve their level of work and life. Instead of making it difficult for them, digitalization and automation must be celebrated as an era where cyber elements can help human work.

Gamification is one of the digitization and automation techniques that can be utilized in a job. According to Hamari \& Parvinen (2018), gamification is simply interpreted as a method in which our reality blends slowly into video games. It manifests in every service, system, and organizational structure that is produced in such a way that it can offer a positive and pleasant experience like playing video games.

In its development, gamification offers a great deal of research development. Huang et al., (2018) explained the relationship between gamification and students' increasing learning abilities. On the other hand, Radovick et al., (2018) showed how gamification helps the treatment of children who are deficient in hormones. The researchers also see how gamification help in losing weight (Kurtzman, 2018) and mental health (Cheng et al., 2018). Thus, it can be drawn into conclusion that the elements of the game, to some extent, can encourage the creation of a person's motivation to complete the work.

However, in the research of gamification, there are still links that have not been connected. Gamification research is still limited in the world of education, sports, and health. There is still very little gamification found in the field of human resource management or employment. Understanding gamification in this field means understanding how industry 4.0 works. With a tremendous counter-push, it is fitting that research on gamification and its relation to labor must be encouraged.

In this regard, there are also contradictions in the ideals of gamification to improve the mental capital and human thought which are assumed able to help workers to be more motivated and improve their performance. The research from Meyer (2008), Mekler et al 
(2013), and Abramovich (2013) found that gamification elements such as instant feedbacks and badges in a certain degree can adversely affect one's motivation.

By referring to the research problems and gaps, the researchers conducted research on the influence of gamification towards the work motivation of online transportation. Online transportation is one of the disruptive modes of transportation that is correlated with gamification and industry 4.0. With automation, the driver can order transportation in the form of a motorbike or car to deliver to the destination in just a few steps.

In the Go-Jek application (one of the online motorcycle-taxi applications), there are gamification elements such as points, penalties and prizes, instant feedbacks, performance, and so on. This gamification is considered interesting to be studied, given that Go-Jek has a total driver of 900,000 and serves 15 million users in Indonesia. This number is actually the largest compared to other online transportation applications.

Based on the explanation above, the aim of this study is to find out how much influence the gamification has motivated Go-Jek partners.

\section{LITERATURE REVIEW}

Marczewski (2013) proposed that gamification is the application of metaphors in games to real-life work to influence behavior, improve motivation, and increase interaction. Gamification uses natural behavior of humankind that is human preferences for games. Gamification can be used to give more meaning to the work done by an individual. This is expected to give someone a sense of pride when doing a job.

This study uses gamification elements from Khaleel et al (2013 which include: points, levels, achievement badges, virtual goods, leaderboard, and virtual gifts. In simple terms and elements, it can be illustrated dynamically in Table 1 below.

Table 1 - Game Elements

\begin{tabular}{|c|c|}
\hline Game Mechanism & Game Dynamics \\
\hline Points & Rewards \\
\hline Level & Status \\
\hline Badge Achievement & Achievement \\
\hline Virtual Goods & Compression \\
\hline Leaderboard & Altruism \\
\hline Virtual Gifts & . \\
\hline
\end{tabular}

Source: Khaleel et al. (2016).

According to Scheiner \& Witt (2016), points represent feedback from the performance performed by an individual. Points in Go-Jek include redeemable points, a point that can be exchanged for objects in the real world. In Go-Jek, when the driver reaches a certain point, the driver will get an amount of incentive money. In this case, Mekler et al., (2013) revealed that points can increase motivation intrinsically.

On the other hand, level according to Scheiner \& Witt (2016) is something that indicates the previous performance of the user. Users can level up if they have completed several targets. Levels in this case can increase competition among users. Whereas, badge achievement based on the research from Abramovich et al., (2013) is a symbolic reward given after completing certain tasks. The badge can be seen clearly by other users so that other users know the ability or knowledge of the badge owner.

Moreover, Werbach and Hunter (2012) described leaderboards as an increase in the motivation of the users. Being able to see the points of other users, the users can increase the competitive spirit from others. Virtual goods and virtual gifts are one of the gamification elements where users get virtual feedback depending on the performance of their tasks.

Kapp (2013) mentioned that gamification can be seen as an effort to increase the use of game elements to improve someone's motivation. Furthermore, the mechanism, aesthetics, and logic of the game can entice someone, motivate action, promote learning, 
and solve problems. Gamification is an important key in understanding the complexity of the workforce in industry 4.0.

The operationalization of work motivation in here will refer to the $3 \mathrm{C}$ motivational model of Kehr (2004). In accordance with that, there are three components related to work motivation which are described in three intersecting circles. The three components are explicit (self-attributed) motives, implicit (unconscious) motives and perceived abilities.

Kehr (2004) wrote that implicit motives are related to unconscious needs and basic human needs. In general, implicit motives cannot be accessed consciously, this motive arises in the subconscious state and can lead to attitude and behavior preferences. This motive is built in the initial phase of someone. McLelland (1995) added that this motives consists of power, reward, and affiliation. Power refers to domination and social control whereas rewards refer to circumstances when a standard is met or exceeded. Last but not least, affiliation refers to when social relations intensely build up.

Meanwhile, Kehr (2004) explained explicit motives as the reason for someone to give attribution to themselves. Explicit motives are strongly influenced by social demands and normative pressure. Other than that, perceived abilities refer to the concept of competence that is a person's capacity to interact efficiently with their environment. Perceived abilities are influenced by past abilities, social support, models, and attributions inherent in someone. Past performance can make someone feel capable of doing the same thing.

Kehr (2004) also believed t the achievement of the above components can refer to the emergence of intrinsic motivation: when a person concentrates and likes to do the activity. However, when one of the two components of motivation (explicit/implicit) is not optimal, one can be called demotivating. In this case, a will is certainly needed. Willingness can temporarily maximize motivation but not in the long term because it can cause health issues.

\section{METHODS OF RESEARCH}

This study is explanatory research done by using a quantitative approach. The respondents of the research are Go-Jek partners who have worked for more than one year. The study was conducted at Go-Jek partners in Bandar Lampung region. There are 100 people used as the samples of this study. The data collection was performed by one-shot incidental sampling where the data were collected simultaneously in a period of time. The data collection was carried out from October 2018 to September 2018.

The independent variable in this study is the gamification elements $(X)$ from Khaleel et al., (2013) while the dependent variable is work motivation $(Y)$ that is adapted based on the research from Kehr (2004). Furthermore, this study was also performed by using questionnaires as data collection instruments. The respondents were identified based on the gender, age, income, and education level. The analysis will be done in descriptive and explanatory techniques by using Analysis of Variance (ANOVA).

The following table illustrates the operationalization of those variables:

Table 2 - Variable Operationalization

\begin{tabular}{|c|c|c|c|}
\hline Variables & Indicators & Items & Source \\
\hline \multirow[t]{3}{*}{ Work Motivation (Y) } & Implicit motivation & $\begin{array}{l}\text { - Rewards } \\
\text { - Achievement }\end{array}$ & \multirow[t]{3}{*}{ Kehr (2004) } \\
\hline & Explicit Motivation & $\begin{array}{l}\text { - Competition } \\
\text { - Status }\end{array}$ & \\
\hline & Perceived abilities & Self Expression & \\
\hline \multirow[t]{5}{*}{ Gamification (X) } & Points & $\begin{array}{l}\text { - Bonus } \\
\text { - Power }\end{array}$ & \multirow[t]{5}{*}{ Khaleel et al., (2013) } \\
\hline & Level & $\begin{array}{l}\text { - Performance } \\
\text { - Target }\end{array}$ & \\
\hline & Badge Achievement & $\begin{array}{l}\text { - Ability } \\
\text { - Knowledge }\end{array}$ & \\
\hline & Virtual Gifts & $\begin{array}{l}\text { - Feedbacks } \\
\text { - Social Relation }\end{array}$ & \\
\hline & Leaderboard & Competitiveness & \\
\hline
\end{tabular}




\section{RESULTS AND DISCUSSION}

Descriptive analysis was carried out on each indicator and its derivative items. The elements from Khaleel et al., (2013) were used in the concept of gamification (variable X) while work motivation (variable Y) adapted the concepts from Kehr (2004). Both two variables were operationalized into 14 items and then used as questions in the questionnaire. Based on the results of the descriptive analysis in Variable $X$, the highest value of mean can be seen in statement number 5 that is equal to 4.1 .

"I am pursuing a high rating in Go-Jek Partner to show my good performance" "Saya mengejar rating Mitra Go-Jek yang tinggi untuk menunjukkan performa saya yang baik')

This shows that the rating or achievement badge in Go-jek works well as a sign that they have good abilities in serving their customers. Rating is the only sign of appreciation that introduces Go-Jek partners to their customers. Furthermore, this element is an important element because it can act as the identity of Go-Jek partners in carrying out their work. Whereas, the lowest mean occurs in variable $X$ (bonus) which states that,

"The points are based on the work I do" ("Implementasi points sesuai dengan pekerjaan yang saya lakukan").

The statement above has a mean value of 3.6 with a neutral tendency. This indicates that the point system that should provide bonus benefits is not working well at Go-Jek. The points are actually crucial in gamification. Implementing an inappropriate distribution of points will decrease one's work motivation. In variable $Y$, the statement which has the highest mean is "reward" with a mean value of 4.1 .

"Rating and tips from customers makes me more excited at work" ("Pemberian rating dan tips dari pelanggan membuat saya lebih bersemangat dalam bekerja")

Ratings and tips are elements of gamification that have a direct impact on respondents. This is related to basic human needs, meaning that they have good performance in their jobs. This indicates that instant feedback is one of the crucial elements in the gamification process. Then, the statement which shows the lowest mean value in variable $Y$ is "competition" with a value of 3.5 .

"The works system in Go-Jek increases the sense of competition within me" ("Sistem bekerja Go-Jek meningkatkan rasa kompetisi yang ada dalam diri saya")

Competition is a basic human nature. Competition stimulates the feeling that their existence must be efficient in the environment. However, Go-Jek applies something else by making a random transaction system that makes the values of the competition go down even though it does not reduce other motivational values. To measure the significance of the influence between variables, the researchers refer to the following ANOVA table:

Table 3 - ANOVA Test

\begin{tabular}{|c|c|c|c|c|c|}
\hline Model & Sum of Squares & Df & Mean Square & $\mathrm{F}$ & Sig. \\
\hline 1 Regression & 439.879 & 1 & 439.879 & 54.496 & $.000^{\mathrm{a}}$ \\
\hline Residual & 791.031 & 98 & 8.072 & & \\
\hline Total & 1230.910 & 99 & & & \\
\hline
\end{tabular}

a. Predictors: (Constant), $X$

b. Dependent Variable: $Y$

It is known that the value of F-count is $54.496, F$ table is 3.31 , Sig count is 0.000 , and Sig $n$ is 0.05 . This means that the value of $F$ count $\geq F$ table $(54.496 \geq 3.37)$ or Sig count $0.000 \leq$ Sig $\mathrm{n}$ 0.05. It can be concluded that there is a significant influence between gamification and work motivation of Go-Jek Partner. The results of the study show that gamification can stimulate implicit and explicit motivation through the elements contained in it. The gamification elements allow Go-Jek partners to choose the route and type of service. This leads to a feeling of power that is closely related to implicit motivation. Furthermore, gamification elements such as the rating system and instant feedback generate more 
motivation which indicates their good performance at work. This also raises affiliations which mean that there has been a good social relationship between Go-Jek and its customers. The results of this research also confirmed the research from Huang et al., (2018), Radovick et al., (2018), and Kurtzman (2018) who associate gamification with the changes in a person's attitude and behavior. If the other previous studies related it to education, sports, and health, this study emphasized that gamification has a fairly close relationship with work motivation.

This study also found that the gamification elements in Go-Jek tend to be easy to do so that the majority of application users rarely experience technical issues that will cause negative consequences on Go-Jek partners' perceptions. In this regard, those who have good knowledge and game literacy tend to have better work motivation.

The variety of points and rewards also have an effect on motivation. Rewards need to be considered in industry 4.0 so as the desire to be more appreciated needs to be improved. In this case, the presence of virtual gifts and instant feedback from Go-Jek customers attracted the attention of Go-Jek partners. This needs to be taken into account because altruism has a strong correlation in increasing the work motivation of Go-Jek partners.

\section{CONCLUSION}

The gamification elements have a strong influence on one's work motivation. Elements such as points, rewards, instant feedbacks, the power to choose work services have a strong relationship with the emergence of intrinsic motivation, which in this case, is related to the formation of the implicit and explicit motivation of someone. From these results, it can be said that the work industry 4.0 can cover the elements of the game in the working system to increase one's work motivation.

Go-Jek as a newly established company since 2014 has plenty of space to grow. Gamification elements can still be maximized by using virtual gifts and leaderboards to encourage better levels of affiliation and competition. In general, this research is a preliminary study that is related to the relationship of gamification with the work motivation or work performance of someone. Future studies can focus on a person's literacy level when playing games and their relation to work motivation. Therefore, age and gender issues may need to be taken into account for the next research topic.

\section{REFERENCES}

1. Abramovich, S., Schunn, C., \& Higashi, R. (2013). Are badges useful in education?: It depends upon the type of badge and expertise of learner. Educational Technology Research and Development, 61(2), $217-232$.

2. Cheng, V. W. S., Davenport, T. A., Johnson, D., Vella, K., Mitchell, J., \& Hickie, I. B. (2018). An App That Incorporates Gamification, Mini-Games, and Social Connection to Improve Men's Mental Health and Well-Being (MindMax): Participatory Design Process. JMIR mental health, 5(4), 110-118.

3. Hamari, J., \& Parvinen, P. (2018). Introduction to the Minitrack on Gamification. Proceedings of the 51st Hawaii International Conference on System Sciences.

4. Huang, B., Hew, K. F., \& Lo, C. K. (2018). Investigating the effects of gamificationenhanced flipped learning on undergraduate students' behavioral and cognitive engagement. Interactive Learning Environments, 2, 1-21.

5. Kapp, K. M. (2013). The Gamification of Learning and Instruction Fieldbook: Ideas Into Practice, USA: John Wiley \& Sons.

6. Kehr, H. M. (2004). Integrating implicit motives, explicit motives, and perceived abilities: The compensatory model of work motivation and volition. Academy of management review, 29(3), 479-499.

7. Khaleel, F., \& Ashaari, N., \& Tengku, W., Tengku, S. M., Tengku, W., \& Ismail, A. (2016). Gamification Elements for Learning Applications. International Journal on Advanced Science, Engineering and Information Technology, 6(6), 54-62. 
8. Kurtzman, G. W., Day, S. C., Small, D. S., Lynch, M., Zhu, J., Wang, W., \& Patel, M. S. (2018). Social Incentives and Gamification to Promote Weight Loss: The LOSE IT Randomized, Controlled Trial. Journal of general internal medicine, 33(10), 1669-1675.

9. MacRae, C. (2018). Just Auto Gamification and the human role in Industry 4.0. Retrieved from https://www.just-auto.com/interview/gamification-and-the-human-role-in-industry40_id181395.aspx.

10. Marczewski, A. (2013). Gamification: A Simple Introduction and a Bit More. USA: Amazon Digital Services.

11. Mekler, E. D., Brühlmann, F., Opwis, K., \& Tuch, A. N. (2013). Do points, levels and leaderboards harm intrinsic motivation? an empirical analysis of common gamification elements. In Proceedings of the First International Conference on gameful design, research, and applications (pp. 66-73).

12. Meyer, K. (2008). Do rewards shape online discussions? Journal of Interactive Online Learning, 7(2), 126 - 138.

13. Radovick, S., Hershkovitz, E., Kalisvaart, A., Koning, M., Paridaens, K., \& Kamel Boulos, M. (2018). Gamification concepts to promote and maintain therapy adherence in children with growth hormone deficiency. Multidisciplinary Scientific Journal, 1(1), 71-80

14. Werbach, K., \& Hunter, D. (2012). For the Win: How Game Thinking Can Revolutionize Your Business. Philadelphia: Wharton Digital Press. 